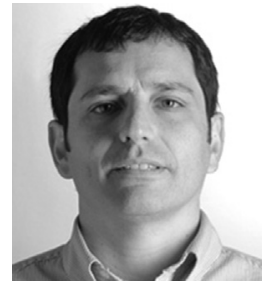

\section{A NEW PERSPECTIVE ON BIBLIOMETRIC DATA: MOVING OUT OF THE MAINSTREAM}

To the Editor:

As researchers involved in bibliometrics, we became very interested in an editorial by Meyers ${ }^{1}$ recently published in the Journal, in which most of the common metrics used to assess a journal were dissected. In agreement with Meyers's statement that "standard metrics are meaningless alone," 1 we thought

\footnotetext{
The Editor welcomes submissions for possible publication in the Letters to the Editor section that consist of commentary on an article published in the Journal or other relevant issues. Authors should: • Include no more than 500 words of text, three authors, and five references. • Type with double-spacing. • See http://jtcs.ctsnetjournals.org/ misc/ifora.shtml for detailed submission instructions. • Submit the letter electronically via jtcvs.editorialmanager.com. Letters commenting on an article published in the JTCVS will be considered if they are received within 6 weeks of the time the article was published. Authors of the article being commented on will be given an opportunity of offer a timely response ( 2 weeks) to the letter. Authors of letters will be notified that the letter has been received. Unpublished letters cannot be returned.
}

that we could strengthen his argument through the use of bibliometric data that are seldom considered in evaluating a journal and that may be of interest to readers and the editorial team.

For instance, the Journal Citation Reports generates a list of journals that are sorted by their impact factor for each of its subject categories, list commonly known as the quartile rankings. Thus the first quartiles represents the top $25 \%$ of the impact factor distribution for a specific subject category, the second quartile between the top $25 \%$ and $50 \%$, the third quartile between the top $50 \%$ and $75 \%$, and the fourth quartile the bottom $25 \%$ of the list.

By using data from the documents published by The Journal of Thoracic and Cardiovascular Surgery from 2010 to 2014, we established some lesser-known metrics. To begin with, we sorted the citing journals by their total number of articles and established to which quartile each of them belonged according to their 2014 impact factor. As Table 1 depicts, most of these journals belong to the first and second quartiles, information that ratifies the quality of the research published by the Journal. In fact, a deeper look into the affiliations registered by the authors who published

TABLE 1. Ranking of the top 10 journals citing articles published by The Journal of Thoracic and Cardiovascular Surgery, according to the total number of cited articles per year

\begin{tabular}{|c|c|c|c|c|}
\hline 2010 & 2011 & 2012 & 2013 & 2014 \\
\hline $\begin{array}{r}\text { Annals of Thoracic } \\
\text { Surgery (Q1/Q2) }\end{array}$ & $\begin{array}{r}\text { Annals of Thoracic } \\
\text { Surgery }(\mathrm{Q} 1 / \mathrm{Q} 2)\end{array}$ & $\begin{array}{l}\text { Annals of Thoracic } \\
\text { Surgery (Q1/Q2) }\end{array}$ & $\begin{array}{r}\text { Annals of Thoracic } \\
\text { Surgery }(\mathrm{Q} 1 / \mathrm{Q} 2)\end{array}$ & $\begin{array}{l}\text { Journal of Thoracic and } \\
\text { Cardiovascular } \\
\text { Surgery }(\mathrm{Q} 1)\end{array}$ \\
\hline $\begin{array}{l}\text { Journal of Thoracic and } \\
\text { Cardiovascular } \\
\text { Surgery (Q1) }\end{array}$ & $\begin{array}{l}\text { Journal of Thoracic and } \\
\text { Cardiovascular } \\
\text { Surgery }(\mathrm{Q} 1)\end{array}$ & $\begin{array}{l}\text { Journal of Thoracic and } \\
\text { Cardiovascular } \\
\text { Surgery }(\mathrm{Q} 1)\end{array}$ & $\begin{array}{l}\text { Journal of Thoracic and } \\
\text { Cardiovascular } \\
\text { Surgery }(\mathrm{Q} 1)\end{array}$ & $\begin{array}{l}\text { Annals of Thoracic } \\
\quad \text { Surgery (Q1/Q2) }\end{array}$ \\
\hline $\begin{array}{l}\text { Interactive } \\
\quad \text { Cardiovascular and } \\
\text { Thoracic Surgery (Q3) }\end{array}$ & $\begin{array}{c}\text { European Journal of } \\
\text { Cardio-Thoracic } \\
\text { Surgery (Q1/Q2) }\end{array}$ & $\begin{array}{c}\text { European Journal of } \\
\text { Cardio-Thoracic } \\
\text { Surgery (Q1/Q2) }\end{array}$ & $\begin{array}{c}\text { European Journal of } \\
\text { Cardio-Thoracic } \\
\text { Surgery (Q1/Q2) }\end{array}$ & $\begin{array}{c}\text { European Journal of } \\
\text { Cardio-Thoracic } \\
\text { Surgery (Q1/Q2) }\end{array}$ \\
\hline $\begin{array}{l}\text { European Journal of } \\
\text { Cardio Thoracic } \\
\text { Surgery (Q1/Q2) }\end{array}$ & $\begin{array}{l}\text { Interactive } \\
\quad \text { Cardiovascular and } \\
\text { Thoracic Surgery (Q3) }\end{array}$ & $\begin{array}{l}\text { Interactive } \\
\quad \text { Cardiovascular and } \\
\text { Thoracic Surgery (Q3) }\end{array}$ & $\begin{array}{l}\text { Interactive } \\
\quad \text { Cardiovascular and } \\
\text { Thoracic Surgery (Q3) }\end{array}$ & $\begin{array}{l}\text { Interactive } \\
\quad \text { Cardiovascular and } \\
\quad \text { Thoracic Surgery (Q3) }\end{array}$ \\
\hline $\begin{array}{l}\text { Journal of Cardiac } \\
\text { Surgery (Q4) }\end{array}$ & Circulation $(\mathrm{Q} 1)$ & PLOS One $(\mathrm{Q} 1)$ & $\begin{array}{l}\text { International Journal of } \\
\text { Cardiology }(\mathrm{Q} 1)\end{array}$ & PLOS One $(\mathrm{Q} 1)$ \\
\hline Circulation (Q1) & $\begin{array}{l}\text { Journal of Cardiothoracic } \\
\text { and Vascular } \\
\text { Anesthesia }(\mathrm{Q} 3 / \mathrm{Q} 4)\end{array}$ & Circulation $(\mathrm{Q} 1)$ & PLOS One $(\mathrm{Q} 1)$ & $\begin{array}{l}\text { International Journal of } \\
\quad \text { Cardiology (Q1) }\end{array}$ \\
\hline $\begin{array}{c}\text { Journal of Thoracic } \\
\text { Oncology (Q1) }\end{array}$ & $\begin{array}{l}\text { Journal of Cardiac } \\
\text { Surgery (Q4) }\end{array}$ & $\begin{array}{l}\text { General Thoracic and } \\
\text { Cardiovascular } \\
\text { Surgery (N/I) }\end{array}$ & $\begin{array}{l}\text { Journal of Cardiothoracic } \\
\quad \text { Surgery }(\mathrm{Q} 4)\end{array}$ & $\begin{array}{l}\text { Journal of Cardiothoracic } \\
\text { and Vascular } \\
\text { Anesthesia }(\mathrm{Q} 3 / \mathrm{Q} 4)\end{array}$ \\
\hline $\begin{array}{l}\text { Journal of Vascular } \\
\text { Surgery (Q1/Q2) }\end{array}$ & $\begin{array}{l}\text { General Thoracic and } \\
\text { Cardiovascular } \\
\text { Surgery (N/I) }\end{array}$ & $\begin{array}{l}\text { Journal of Cardiothoracic } \\
\text { and Vascular } \\
\text { Anesthesia }(\mathrm{Q} 3 / \mathrm{Q} 4)\end{array}$ & $\begin{array}{l}\text { Catheterization and } \\
\text { Cardiovascular } \\
\text { Interventions }(\mathrm{Q} 2)\end{array}$ & $\begin{array}{l}\text { Journal of Thoracic } \\
\text { Disease (Q3) }\end{array}$ \\
\hline $\begin{array}{l}\text { Journal of Heart and Lung } \\
\text { Transplantation (Q1) }\end{array}$ & $\begin{array}{l}\text { Journal of Vascular } \\
\text { Surgery (Q1/Q2) }\end{array}$ & $\begin{array}{l}\text { Journal of Cardiac } \\
\text { Surgery }(\mathrm{Q} 4)\end{array}$ & Circulation $(\mathrm{Q} 1)$ & $\begin{array}{c}\text { Asian Cardiovascular and } \\
\text { Thoracic Annals (N/I) }\end{array}$ \\
\hline $\begin{array}{l}\text { Journal of Cardiothoracic } \\
\text { and Vascular } \\
\text { Anesthesia }(\mathrm{Q} 3 / \mathrm{Q} 4)\end{array}$ & $\begin{array}{l}\text { Journal of Cardiothoracic } \\
\text { Surgery (Q4) }\end{array}$ & $\begin{array}{l}\text { Journal of the American } \\
\text { College of Cardiology } \\
\text { (Q1) }\end{array}$ & $\begin{array}{l}\text { Journal of Cardiothoracic } \\
\text { and Vascular } \\
\text { Anesthesia (Q3/Q4) }\end{array}$ & $\begin{array}{l}\text { Journal of Cardiac } \\
\text { Surgery }(\mathrm{Q} 4)\end{array}$ \\
\hline
\end{tabular}

Quartile distribution was estimated from the Journal Citation Reports 2014 Science Edition database. $Q 1$, First quartile; $Q 2$, second quartile; $Q 3$, third quartile; $Q 4$, fourth quartile; N/I, not indexed by Journal Citation Reports 2014 Science Edition database. 
Authors have nothing to disclose with regard to commercial support.

their research in The Journal of Thoracic and Cardiovascular Surgery revealed that the top 5 institutional contributors were Harvard University, followed by the Cleveland Clinic Foundation, Mayo Clinic, University of Toronto, and University of Pennsylvania. Another important aspect to consider is the international visibility of the Journal, as most researchers are interested in communicating their findings globally. During this 5-year period, the country that contributed the most was the United States, with $46.8 \%$ of the published documents, followed by Japan $(7.5 \%)$, Italy $(7.2 \%)$, Germany $(7.1 \%)$, and Canada (7.1\%).

According to the analysts Thomson Reuters, a highlycited paper is defined as "a paper that belongs to the top $1 \%$ of papers in a research field published in a specified year. The $1 \%$ is determined by the highly cited threshold calculated for the research field in the specified year." 2 Well, the fact that The Journal of Thoracic and Cardiovascular Surgery published, on average, 3 highly cited papers annually is probably unknown to most readers.

Because of the length of this letter, we only included a few metrics that are easier to understand and that, in our view, are more valuable to researchers when seeking for an appropriate journal to submit their manuscripts. Perhaps it is time to include some of these metrics on journals' Web sites to assess the potential impact of each journal.

Erwin Krauskopf, PhD ${ }^{a, b}$
Maria Cecilia Gamboa, PhD
${ }^{a}$ Facultad de Ciencias Biologicas
Universidad Andres Bello
Santiago, Chile
${ }^{b}$ Fundacion Ciencia \& Vida
Santiago, Chile

This work was supported by Proyecto Financiamiento Basal (PFB-016).

\section{References}

1. Meyers BF. Do we need a bibliometrician to know which way the wind is blowing? J Thorac Cardiovasc Surg. 2016;151:23-4.

2. Thomson Reuters. Incites Essential Science Indicators. Available at: http:// ipscience-help.thomsonreuters.com/incitesLiveESI/ESIGroup/citationThresholds/ thresholdHighlyCited.html. Accessed January 2016.

http://dx.doi.org/10.1016/j.jtcvs.2016.01.042

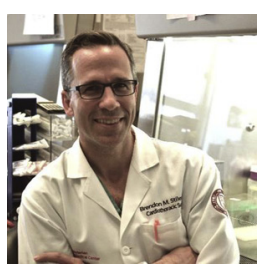

METRICS MATTER FOR KNOWLEDGE WORKERS LIKE US Reply to the Editor:

The Journal should examine multiple bibliometric end points to compile practical data regarding the importance of its publications.

I read with interest the letter written by Drs Krauskopf and Gamboa. ${ }^{1}$ It reflects on the speed and breadth of digital information dissemination today that an editorial published in the Journal caught the attention of 2 bibliometricians in Chile. They write in response to Dr Bryan Meyers' timely editorial, "Do We Need a Bibliometrician to Know Which Way the Wind Is Blowing?" In it, Dr Meyers describes the dramatic growth of measurement tools, but also the challenges inherent with these tools. ${ }^{2} \mathrm{He}$ argues that these challenges are particularly apparent for subspecialty journals, which must be concerned with disseminating practical information of daily use to readers that may not necessarily be "impactful" when evaluated by standard metrics. He further suggests that journals such as the Journal also have an inherent responsibility to support the early work of young surgeon-scientists, to disseminate experience through case studies, and to highlight our specialty's values, such as surgical education and professionalism. None of these endeavors generate high-impact publications. They may actually depress a journal's impact factor.

Drs Krauskopf and Gamboa write in support of Dr Meyers' contention that "standard metrics are meaningless alone." They emphasize the high quality of journals that cite articles published in the Journal, the quality of institutional contributors, the international visibility, and the remarkable number of "highly cited" articles published by the Journal. None of this would be appreciated by simply looking at impact factor alone.

So the question remains: Do we need bibliometricians to know which way the wind is blowing? Of course! Almost everything about our specialty has been built on the idea of metrics. No matter how much pride we take in our manual dexterity, cardiothoracic surgeons are without doubt "knowledge workers," a term coined in 1957 by Peter Drucker, a well-known management guru. Even then, he anticipated our eventual shift to a data-driven society. Drucker wisely said, "What gets measured gets improved." ${ }^{3}$ The key is to figure out what information is needed and to ask the right questions. That should certainly be the mandate of the Journal. The Journal should critically review its publications and evaluate citations and impact factor, but also consider newer metrics such as downloads, H-index (the number of articles at or above a given citation level equal to the value of a citation threshold), 